\section{1－1 胸部食道㾂に対する術前画像診断に基づ く合理的上梌隔・顠部リンパ節郭清}

\section{鹿児島大学第 1 外科}

福元俊孝, 貴島文雄, 徳田和信, 若松大介, 白尾一 定, 島田麻里緒, 草野 力, 夏越祥次, 馬場政道, 吉 中平次, 愛甲 孝

【目的】教室では胸部食道癌に対して積極的に 3 領 域郭清を施行してきたが, 顠部・上縱隔リンパ節転移 率は $35.7 \%, 31.8 \%$ と高率であり，この領域の郭清を 十分行なうことは根治性を高めるためには不可欠であ る. しかし大きな手術侵襲を伴うのも事実である。 そ こで我々は1990年からは術前超音波診断に基づいた合 理的顠部・上緥隔リンパ節郭清の適店を検討し, 頸胸 移行部は縦隔側から徹底郭清を行なってきた。そ結 果, 再発・遠隔成績に於いても 3 領域郭清と変わらな いことを第65回の本会で発表した. とくにこの領域の 広汎な徹底郭清は気道系の血行不良や咳濑反射の低下 を生じやすく, 術後合併症の面からも頚部上椎隔の郭 清は慎重を要する．また，気管支動脈を含めた気管固 有鞘の温存が気管粘脱ひいては術後肺機能にとって非 常に重要である. 今回は 1 ) 反回神経周囲リンパ節の 郭清，2）気管支動脈，3）気管固有輎，4）迷走神 経肺脿枝の温存を中心に供臨する。

【手術手技】1) 開胸は通常右第 5 肋間で行う，2）栓隔 胸膜を奇静脈下娽から上方に向かい, 前方は気管前面 で, 後方は椎体前面に治い鎖骨下動脈が十分露出する まで切開する. 3 ) 奇静脈を 2 重結㷊切離する. この時 右気管支動脈に十分注意し, 周囲の結組樴を含めてテ ーピングしておく． リンパ節郭清 1) 右迷走神経に柔 らかい血管テープをかけ、軽く轶引しながら右気管周 囲リンパ節を郭清する。この時, 上述したように気管 固有輎を残すようにすることが大事である. 2)ついで 右106最上リンパ節をバブコップ鉗子で把持しながら, 反回神経を偒つけないないように郭清する.この時鎖骨 下動脈にテープをかけて上方に杽引しながら郭清する とやりやすい． 3)さらに最上リンパ節に連䌇する右頚 部傍食道リンパ節 (No. 101)も可及的に胸腔内から郭清 する.この操作で甲状腺下檑付近まで郭清できる．4） 気管左側の郭清は食道を出来るだけ高位で切睢し, 下 方へ反転轶引したのち行なう. 大 動脈弓の上方で左反 回神経に柔らかい血管テープをかけ, 軽く率引しなが ら左最上リンパ節から頱胸移行部を可及的に上方まで （左NNo.101を含めるように）郭清する. 5) ついで大動 脈弓下の左気管気管支リンパ節 を郭清する. また, 教 室では後梠隔を再建ルートに選 択しているので, 気管 支動脈は肋間枝を結染切離し，出来るだけ大動脈根部 まで周囲結組織をも郭清する。，7）右迷走神経の肺䑏 枝を温存しながら気管分蚑部り ンパ節を部清する。
$\mathrm{V} 1$ 1-2 胸部食道癌に対するリンパ節郭清 一とくに胸腔内アプローチからの上縌隔郭清一

大阪府立成人病センター外科

甲 利幸、安田卓司、今岡真義、古河 洋、平塚正弘、 石川 治、佐々木洋、亀山雅男、大東弘明、中森正二、 中野博史、岩永 剛

近年、胸部食道癌に対して、頸・胸・腹部にわたる 3 領域リンパ節郭清の必要性が提唱されてきた。3 領 域郭清の意義は従来の 2 領域郭清に単に頸部郭清が加 えられたのではなく、頸部之上縦隔とを連続的に郭清 することにより上縦隔の郭清がより徹底化されること にあると考えられる。われわれは、胸腔内より上縦隔 リンパ節郭清の徹底化を行っており、今回、われわれ の行っている胸腔内アプローチからの上縦隔リンパ節 郭清手技および治療成績について報告する。

【手術手技】手術は占居部位のいかんに拘らず、左 側卧位、右第 5 肋間開胸にて行う。上縦隔郭清は、胸 部食道を周囲結合織を食道側につけるようにして全長 にわたり䟝離した後に行う。この際、右気管支動脈は 原則として切離し、胸管も切除している。右鎖骨下動 脈を露出し、右鎖骨下動脈を上方に圧排して、右反回 神経を確認、温存しながら、右反回神経沿いのリンパ 節を頸部まで郭清。左反回神経沿いリンパ節は、まず、 気管左側壁から、リンパ節、左反回神経を含めた周囲 結合織を䟝離する。この結合織の中から左反回神経を 確認し、血管テープでtapingして頸部まで左反回神経 を遊離したのち、結合織を含めてリンパ節を一塊にし て郭清する。これら左右反回神経沿いリンパ節の郭清 の際、胸部食道は切断せずに牽引することにより頸部 までの郭清が容易になり、甲状腺下極まで郭清できる。 次ぎに、左気管気管支リンパ節の郭清を行う。さらに、 以前は全例行っていたが、最近では、主としてIu症例 に対して気管前リンパ節の郭清を行う。

【治療成績】上縦隔の徹底郭清が行われなかった 1982 年以前の症例と比較すると、5生率（Cミ1）は $30 \% に$ 対して $46 \% （ p<0.05 ）$ と向上した。再発形式別にみる 之、 5 年累積上縦隔再発率が $36 \%$ から $9 \%$ に著減（ $\mathrm{p}<0$. 01）し、遠隔臓器再発や、その他の再発率には大差は なく、治療成績が向上したのは上縦隔再発の減少によ るものであった。手術直接死亡率も5\%から $2 \%$ に低下 し、上縦隔郭清による合併症の増加は認めらなかった。 また、気管全周にわたる郭清を行っても気管壊死等の 合併症はみられなかった。

【結語】胸部食道癌に対する上縦隔郭清は胸腔内アプ ローチから十分に行うことができると考える。この術 式の利点として、頸部からのアプローチを加えた郭清 に比べて気管への下甲状腺動脈支の損傷は殆どなく、 気管支動脈を切断しても気管壁への血流は保たれ、郭 清による肺合併症の増加がないことがあげられる。 


\section{$\mathrm{V} 1$ 1 - 3部食道的に対する反回神経周囲リ ンパ節の郭清}

国立がんセンター中央病院外科

日月裕司、加藤抱一、渡辺 䙾

[目的] 胸部食道㾂からの反回神経周囲リンパ節へ の転移頻度が高いことはよく知られている。そのた めに我が国においては綎隔郭清の中でこの部位の重 要性が强調されてきた。その結果、リンパ節再発は 減少し術後の生存率も上昇し、その有奻性ばかりが 強調されている。しかし、郭清に伴ら合併症として 反回神経麻瘦の発生頻度が $30 \%$ を越えるようでは、 とても一般にそして欧米に受け入れられる手技とは いえない。そこで、実際の郭清の手技を供覧すると ともに、術後の反回神経麻瘦の発生率を示し、反回 神経麻瘦発生が少ない手技を検討する。

[手技] 右側の郭清: 右迷走神経の真上で胸膜を切 開して神経を露出し、鎖骨下動脈下縁でtapingする。 右反回神経を捜すのは鎖骨下動脈の前面ではなく下 縁から背側がよい。はじめに右反回神経を頭側へ十 分にたどり、その全長を露出し周团を剥離しおく。 その後に右反回神経以外の組織を郭清する。

左側の郭清 : 食道を剥離し、綿テーブで毫引する。 周囲の剥離を進める前に左反回神経を確認しておく。 食道切離後に気管全体を前方へ圧排して綎隔左側を 展開する。大動脈弓上縁の高さで左反回神経を確認 しtapingする。左反回神経の前方に迷走神経の心臓 支が縦走し、左反回神経と紛らわしい。神経を大動 脈弓の下に追い、左反回神経であることを確認する。 神経を頭側へ十分にたどり、その全長を露出し周囲 を剥離しおく。頭側では気管に近づくので注意する。 その後に左反回神経以外の組織を郭清する。

[成績] 1990 年から1995年までの最近 6 年間に、 演者を術者として右開胸と頝部操作で反回神経周囲 の郭清を行ら手術を 72 例に行った。術前から麻疸 を認めた 2 例を除き 15 例に手術翌日の気管支鏡検 查で反回神経麻㾇を認めた。そのうちの 11 例はそ の後の気管支鏡検査と耳鼻科の検查で麻瘦が回復し たことを確認した。

[結論]十分な注意を払った手技により、郭清に伴 5 反回神経麻瘦の発生は減少できる。高率の反回神 経麻瘦の発生を予後改善のためにやむを得ないもの としてはいけない。

\section{1-4 朐部食道癌に対する三領域リンパ節郭清 術式}

兵庫医科大学第 1 外科

豊坂昭弘、中井謙之、土生秀作、竹内雅春、

中村清昭、桑原幹雄、岡本英三

胸部食道癌では、胸部上部の反回神経周囲沿いに高 率に転移がみられ、頸部リンパ節に移行することから、 頸胸移行部の郭清が本術式の最重要点の一つと考えら れる。教室では、1988年から三領域郭清術式を標準術 式として採用してきたが、本術式では術後の呼吸器合 併症が問題視されている。我々は胸部および頸部両方 から両側反回神経を確認し、伸展性の優れた血管テー プを用いtapingすることにより、神経の損傷を回避し、 頸部及び胸部から十分な郭清を行っているので、我々 の術式を供覧する。

〔対象〕1995年までに三領域リンパ節郭清が施行され たのは41例である。〔手術手技〕胸部操作 : (1)開胸後、 奇静脈を離断、気管支動脈は温存する。䋛隔胸膜を上 大静脈後縁に沿い切開し鎖骨下動脈を露出、右迷走神 経にtapingした後、右反回神経にtapingする。これに より右反回神経周囲の右最上部リンパ節を一塊として 郭清する。(2)左反回神経は食道をtapingし、背側に牽 引し、気管を前方へ圧排すると大動脈弓上縁で確認で き、tapingする。これにより安全に左上縦隔リンパ節 を一塊として郭清する。(3)更に左反回神経を下方に追 求し、大動脈弓下とボタローリンパ節を郭清する。切 離後には左肺動脈が露出する。(4)大動脈は下方まで外 膜を露出し、食道後壁との間を十分遊離する。この際、 胸管は通常切離する。(5Iuの部で食道を仮離断し、食 道肛門側端を挙上し、肛門側に向かって気管分岐部お よび左右気管支リンパ節を十分郭清する。この際、右 迷走神経は肺枝を温存し、食道枝のみ切離する。(6)上 大静脈と気管との間の気管前リンパ節を一塊として右 腕頭動静脈から切離する。この際、右迷走神経から分 岐する心蔵枝は温存する。頸部操作 : 左右反回神経を 確認し、縦隔に追走し、胸部からの連続性を直視する。 縦隔最上部の郭清は、胸部からより頸部からの方が容 易であり、最近では胸部から確認し頸部から行ってい る。またIuの例では頸部操作を先行し、頸部で両側反 回神経にtapingしこれを縦隔内に落とし込むと、胸部 操作で容易に反回神経を確認できる。〔成績〕上縦隔 から頸部にかけての反回神経沿いリンパ節転移は左側 $28.9 \%$ 、右側 $23.7 \%$ で高率であった。術死は 1 例で慢 性萃炎例にみられた。反回神経麻痺はtaping施行後で は25\%にみられたが、いずれも一過性で永久麻痷はな くすべて改善した。三領域郭清後の 5 生率は $58.7 \%$ 、 以前の二領域の $21.5 \%$ に比し著しい改善がみられた。 上縦隔の郭清で反回神経へのtapingは、神経損傷の回 避および十分なリンパ節郭清には必須と考えられた。 
V 1 - 5 進行胸部食道癌における広範井かつ安全 な䋮隔内操作とリンパ節郭清の工夫

\section{杏林大学第二外科}

呉屋朝幸、吉田 治、柳田 修、小井土昭二郎、 福島淳一、興石義彦、中田芳孝、花岡建夫、 [目的] 進行食道癌は治療困難な癌の 1 つであり、 5 年生存率はいまだ低い。最近では進行食道癌に対し各 施設で 3 領域郭清や拡大縦隔内郭清および補助療法な ぞを施行し良好な治療成績の報告がなされている。我 々も進行食道癌に対して徽底した縱隔内操作やリンパ 郭清が必要だと考える。当教室では進行食道癌に対し て癌腫の露出・残存を少なくするため可能な限り食道 周井の結合組織を合併切除しリンパ節の郭清を行う安 全確実な術式を工夫して施行しているので供覧したい。 [郭清範冊] 三領域郭清を行うが、胸部の郭清範囲は 以下の如くである。縱隔胸膜を剥離する線は後方では 胸椎体の右側面、前方は上縦隔では気管右側面まで肺 門では中間気管支まで、下縦隔では心囊の後方まで郭 清する。気管前方の郭清は行わない。左側に対しては 上縱隔では左反回神経を越えて左側の縦隔胸膜まで、 肺門では左主気管支周曲、ボタロー勒帯、左下肺静脈 周囲まで郭清する。下縦隔では＃1 10、\# 111 、 \# 112 の領域を郭清するため大動脈から直接分枝す る肋間動脈以外は大動脈周囲の結合織もすべて郭清す

る。綎隔最上部では椎骨動脈、同静脈、右反回神経周 囲まで郭清を行い頚胸境界部に至る。

[手術操作］緹隔操作は胸椎体の右側面で奇静脈の分 枝 (右肋間静脈や半奇静脈との交通枝) を結禁切離し て奇静脈を縦隔胸膜とともに翻転させる。右胁間動脈 は温存する。この層での操作は縦隔最上部から横隔膜 部まで行う。これにより胸管は食道と共に切除される。 また肺門・下縦隔の操作では右肋間動脈を温存しつつ 大動脈の右側面から前面に向けて大動脈周囲リンパ節 および脂肪織を剥離して左側緹隔胸膜に至る。下縱隔 において右側肺勒帯は合併切除し、左側縦隔胸膜は心 輷の後方で横隔膜から左下肺静脈の高さまで左側肺勒 帯を含め切除する。肺門部では右中間気管支、左主気 管支、下肺静脈周冊リンパ節も郭清する。上綎隔では 気管を牽引挙上しボタロー勒帯および左側反回神経周 井まで郭清する。縱隔最上部では右腕頭動脈・右側反 回神経を確認して頝胸境界部のリンパ節郭清を行う。

[まとめ] 胸部食道癌は周囲に進展しやすく進行した 症例が比較的多い。当教室ではこのような進行食道癌 に対して徹底したリンパ節郭清はもと上り癌腫を露出 ・残存させないよう最大限に周囲結合組織で食道癌病 巣を包むような手術を工夫し施行している。今回の供 覧する手術は周囲結合組織の膜を利用して癌病巣の露 出を防止する手術であり安全かつ確実で広範囲な縦隔 内操作を可能にする安定した術式である。
V $1-6$

胸部食道癌に対する系統的リハ・節郭

清術

横浜市立大学医学部第2 外科

国崎主税、山岡博之、渡会伸治、高橋正純、

金谷洋、舶田久仁郎、田中邦哉、嶋田紘

「目的」胸部食道癌に対して、系統的な3領域郭清

術を施行しているので供覧したい。

「対象」適応は70歳以下の重篤な併存疾患のない 症例で、Iu; $\mathrm{MM}_{3}$ 以深、I Im,Ei;MP以深あるいは No.106転移例、Ei,Imでskip lesionがlしまでに認め られる症例とした。

「手術手技」胸部操作; Anterolateral incision で 第4胁間開胸する。術後呼吸筋力保持のため広背筋 を切離しない。迷走神経を確認後、これを温存し No.106R-Para,106Pre,106recRを連続的に郭清す る。迷走神経から分岐する心臓枝と気管固有鞘を 温存する。次いで、奇静脈を切除し、更に、肋間 動脈を切離分離することにより、右気管支動脈を 長く遊離温存し術野を展開する。食道、気管をそ れぞれ後、左反回神経を確認し、No.106-

recLを郭清する。左迷走神経肺枝を温存しながら 大動脈弓、左肺動脈を十分に露出しNo.106tbLを 郭清する。右気管支動脈が温存できていれば、左 気管支動脈は温存しない。No.106tbRからNo.107 ，109を郭清した後、食道を周囲組織から剥離しな がらNo.111.112を郭清し、胸部操作を終了する。 胸管は肝硬变合併例を除き切除する。頝部操作; 弧状切開後、前頚筋群、胸銷乳实筋、肩甲舌骨筋 を切離し、視野を展開する。頝動静脈にテーピング後、 No.101,104,102 mid,103を連続的に郭清する。こ の際に、迷走神経（反回神経）、横隔神経、副神 経を温存し、胸管は静脈角合流部で切除する。外 側の郭清範囲は鎖骨上神経までとする。第3助間ま で胸骨緹切開を加え、No.106recR，LからNo.101ま で連続的に郭清する。左前頙筋を椎骨前面に䋖縮 し、頚部と胸腔との連続性を断つ。腹部操作; 腹 部リパ節郭清はNo.1,2,3,7,8aまでとし、Ei症例で はNo.16a $a_{1}, a_{2}$ lateroを郭清する。再建は要全胃管、 胸骨後経路を原則とし、肠合は手栈いで行う。胃 管举上の際に、胸骨柄および左鎖骨頭を一部切除 し、胃管への圧迫を解除する。

「成績」本術式はposterolateral incision、第4肋 骨床開胸、広背筋切離症例に比較して術後肺合併 症 $48.1 \rightarrow 25.0 \%$,最高血中ビリ㸝”值 $3.85 \pm 2.7 \rightarrow 1.9$ $\pm 1.2 \mathrm{mg} / \mathrm{dl}$,気管切開施行率 $29.6 \rightarrow 0 \%$, 㨉管日数 8.2 $\pm 6.6 \rightarrow 4.0 \pm 1.4$ 日と術後経過が良好であった。

「結語」本術式は3領域を十分に郭清することが可 能であり、呼吸筋力を保持することにより術後合 併症を減少させ、有用な術式と考えられた。 


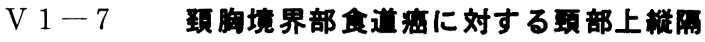 リンパ節郭落}

山口大学第二外科

武田 茂、丹黒 章、林 弘人、安部 俊弘、

岡正朗、鈴木 敞

【目的】頚胸境界部食道癌では、癌腫の拡がりや進行 度により手術術式の選択は多岐にわたる。リンパ節に ついても頸部、上縦隔を中心に様々な転移形態をとる。 一方、術後QOLの面からは喉頭を温存するほうが望ま しいが、根治性との兼ね合いが問題となる。教室では 頝胸境界部食道癌に対し、可及的に喉頭を温存しつつ、 胸腔および頚部より両側反回神経周囲を中心にした徹 底的な縦隔郭清と両側頸部郭清を施行している。

【手術手技】まず左側臥位にて右第 5 肋間で開胸する。 奇静脈を切離した後、右迷走神経本幹に沿って胸膜を 切開し、これを頭側に進めて右反回神経を同定する。 同時に右第 7 肋間より胸腔鏡を挿入しておく。反回神 経周囲を郭清する際、胸腔鏡補助下で行うと接視が可 能となり、神経損傷の危険が少ない。左反回神経にテ 一ピングしNo.1061の郭清を行う。胸腔鏡補助下により 反回神経を損傷することなく胸腔側から甲状腺下極ま での郭清が容易に施行できる。中下縦隔については通 常の胸部食道癌に準じて郭清する。気管分岐部から両 侧気管支周囲を郭清し、食道も食道裂孔まで十分に剥 離しておく。胸腔ドレーンを挿入し閉胸する。次いで 仰臥位とした後、頚部と腹部の 2 チームに分かれて行 う。腹腔操作ではリンパ節郭清の後、Linear cutterを用 いて大彎側胃管を作製する。頸部ではU字切開をおき 両側の郭清を行う。胸鎖乳突筋を率引し、前頚筋群を 切離し、総頝動脈、内颈静脈を露出し迷走神経神経を 温存しながら郭清を行う。食道を気管から剥離し左反 回神経の走行に注意して進めると胸腔内からの郭清の レベルと連続する。右反回神経周囲も同様にして胸腔 内と連続させる。

頝部食道を高位にて離断、断端を全周、全層に術中 迅速病理組織検査に提出し、癌の遺残なきことを確認 する。再建は我々の考案したLarynx-preserving triple stapling technique (LP-TST) にて行う。すなわち、大彎 側胃管を胸骨後経路にて頝部まで挙上し、Linear staplerにて頝部食道を離断、大彎側胃管の先端すなわ ちLinear cutterにて切離した小彎側の先端にセンターロ ッドが位置するようアンビルを装着する。自動吻合器 本体を経口的に挿入、トロッカーをLinear staplerにて 切離した頝部食道の中央より突き出し、アンビルと本 体を合体し吻合を行う。【まとめ】喉頭温存の場合、 反回神経の損傷などに注意しつつも、十分な頝部上縦 隔のリンパ節郭清が必要である。この際、胸腔鏡を使 用し接視することで、より瀻細な郭清が行え、術後合 併症に対しても有用であるると思われた。
V 2-1 胃癌手術における再建術式の工夫一 噴門側胃切除術

山形大学第 1 外科"

重山仁一, 長谷川慗生, 木村青史, 石田一,

星川匡, 貫野 充, 鈴木 晃, 吉村信幸,

川村博司，塚本 長”，千葉昌和 ${ }^{21}$

[目的］われわれは上部胃癌に対して機能を温存し, 術後のQOLを考えた空腸要を間置する噴門側胃切除 術を犬や豚での実験を経て臨床応用している. 今回は この術式の有用性を胃全摘と噴門側胃切除術（以下， 喷切），および喷切例での 3 種類の再建法間で比較し た種々の成績を報告しながら, 再建術式, 透視・内視 鏡所見などをビデオで供覧する.

[対象および方法] 対象は胃全摘322例（男214例, 女108例，平均年齢60歳）および噴切72例（男54例， 女18例, 平均年粭63歳) である. なお, 噴切の再建 法は double tract (38例)，従来の空腸間置 ( 7 例), 新しい空腸間置（27例）の3 種類である。これら の症例で術後のアンケート調査, 上部消化管の透視お よび内視鏡所見などについて検討した．ビデオでは新 しい術式の要点, 工夫や問題点などを供覧する.

[成樍] 種々の術後愁訴, 栄意状態などについてみる と, 食道・残胃吻合を行っていた時の噴切は胃全摘に 比べ不良であった. しかし, 噴切後の再建をdouble tract, 空腸間置に変更してからは胃全摘よりも良好 となった. ところが, この 2 つの再建法では新たに発 生する残胃・十二指腸・肝・胆道・膵の病変に対して ERCPなどのレ線学的・内視鏡的診断や, ESTなどの 内視鏡的治痛が行えないか非常に難しいなどの問題が あった. 犬や豚などの動物実験を経て, 臨床応用して いる空腸をを間置した再建法はこれらの問題を全て同 時にクリアできた。

[再建術式] 噴門側胃切除を癌の占居部位, 大きさ, 深達度などに応じて行う. 再建にあたってはTreitz䩗 帯から約 $15 \mathrm{~cm}$ 肛側の部位から約 $30 \mathrm{~cm}$ 有茎空腸腸 管を作製し，横行結腸間膜を通して挙上する．両側切 離断端が肛側にくるように 2 列に並列し，この部より 自動縫合器を挿入して, 空腸・空腸側々吻合を行い, 一つのとする．逆流性食道炎の防止のため口側先進 部となる約 $2 \mathrm{~cm}$ の腸管は吻合せずに隔壁として残し ておくことが重要である. 吻合部は確実に止血する. その後, 自動吻合器を用いて食道と空腸豆を吻合する 吻合の部位は空腸略の右側，前壁にするとよい，空腸

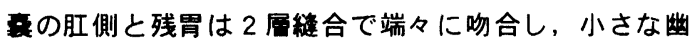
門筋切離術を付加する.

[まとめ]空腸交を間置した新しい術式は残胃の容量 逆流性食道炎, 残胃のみならず, 十二指腸・胆道・膵 病変の検索や内視鏡的治癔という面で非常にメリット の大きい手術々式と思われる. 


\section{$\mathrm{V} 2$ 2-2機能温存を考虐した上部胃癌に対する幽 門保存胃覀全摘兼有茎空腸移植術}

奈良県立医科大学第 1 外科 ${ }^{1}$ 、済生会御所病院外科 ${ }^{2}$ 山田行重 $、$ 渡辺明彦 $、$ 三和武史 1 、阪口晃行 1 、 中島仁一1、松田雅彦、山山田 貴 1 、澤田秀智1、 中谷勝紀 2 、中野博重

【はじめに】我々は1972年11月より、比較的早期の 上部胃癌に対し、内容の急速排出や十二指腸液の逆流 を防止する目的で、幽門保存胃切除術の理論を応用し、 幽門輪部を含め幽門洞部を $1.5 \mathrm{~cm}$ 温存した幽門保存胃 覀全摘兼有茎空腸移植術：pylorus preserving nearlytotal gastrectomy with jejunal interposition (PPNTG) を行っ ている。その術式を紹介し、種々の点から胃全摘後の 食道十二指腸間空腸間置術(Interposition法) およびRouxY法と比較検討した。

【方法】本術式は幽門部を幽門輪部より $1.5 \mathrm{~cm}$ 温存 する以外、通常の胃全摘術と異なる点はなく、従って 幽門上下リンパ節郭清のため右胃大網動脈と右胃動脈 は根部で結禁切離する。約 $40 \mathrm{~cm}$ の有茎空腸を作製し、 結腸後に挙上する。食道と移植空腸との端々吻合は Gambee縫合でおこなっていたが、最近は器械吻合を 用いている。移植空腸と温存幽門部の吻合はまず移植 空腸全層と温存幽門部粘膜の連続縫合を行い、次いで 漿膜筋層を結節縫合にて行っている。術後の上部消化 管透視ではバリウムが分節的に流れて行き、間置空腸 に一旦貯留し、十分に摚找されて幽門輪部の括約作用 により徐々に排出されるのが認められた。今回、臨床 症状、血液検査、脂肪吸収テスト、ガストログラム、 microdensitometory(MD)法など種々の点から胃全摘後の Interposition法およびRoux-Y法と比較して評価を行っ た。

【成續】ダンピング症候群や逆流性食道炎の発生頻 度はPPNTG群ではInterposition群、Roux-Y群に比べ有 意に少なかった。術後体重増加もPPNTG群では他の 2 群よりも良好であった。 ${ }^{131}$ I-trioleinを用いた脂肪吸 収テストにおいてもPPNTG群では良好であった。 ${ }^{99 \mathrm{~m}} \mathrm{Tc}$ を用いたガストログラムにおいてもPPNTG施行 例では正常ボランティアと同様の曲線を示して、50 \%胃内容排出時間は約 20 分であったが、Interposition 施行例では急速排出型を示し、50\%胃内容排出時間 は 5 〜 8 分であった。食事刺激による血清ガストリン 值の変動もPPNTG群では他の 2 群よりも上回ってい た。MD法による骨障害発生頻度でもPPNTG群では他 の 2 群より有意に少なかった。

【結語】PPNTGはダンピング症候群や逆流性食道炎 の発生頻度が少なく、消化吸収能が良好に保たれてお り、運動機能の面からも生理的であり、骨障害発生頻 度も少ないなど良好な成績を得た。PPNTGは上部胃 癌に対し機能温存、Quality of lifeの面からも有用な術 式であると考えられる。

\section{$\mathrm{V} 2-3$ 上部早期胃癌に対する迷走神経肝枝・腹腔 枝温存リンパ節郭清をともなう胃全摘術後、回結腸間 置法再建術式}

東京慈恵会医科大学外科学講座第 2

高山澄夫, 平井勝也, 関根千秋, 緒方直人, 二村浩史, 堤 純, 樫村弘隆, 佐野芳史, 大谷昌道, 井上好央, 青木照明

【目的】上部早期胃癌に対する噴門側胃切除術は、逆 流性食道炎を主とした術後愁訴が高率に発生する危惧 があり、再建法の工夫が試みられているが、手技が繁 雑なわりに術後貯留能の確保が十分とは言えず、残胃 生理機能の面からる、その意義に問題が残されている。 この観点より、我々は胃上部 $1 / 3$ 以上の切除を余儀なく される症例、をた胃上部に限局してる楔状切除で根治 不能な早期胃癌に対しては、積極的に胃全摘術を行い、 回結腸間置法再建術を行っている。乙の再建方法は、 術後の十分な貯留能の確保が可能であり、回盲弁の機 能に上り逆流性食道咨の発生が防止される。㐬間置 結腸の長さ、再建後の固定の工夫によりダンピング症 候群の発生も防止可能であり、術後 Q O L の改善につ ながっている。リンパ節郭清においては、 sm癌でも迷 走神経肝枝・腹腔枝を温存して 2 群リンパ節の郭清が 可能であり、根治性の面でも問題は無い。また、同神 経の温存により、肝、胆、膵機能および小腸、間置回 結腸の運動機能の保全も可能となる。

【手術手技】十二指腸の授動とともと後腹膜切開を下 方へ延長、回結腸動脈起始部が確認でをるまで上行結 腸を十分に左方へ授動しておく。迷走神経肝枝を温存、 食道を遊離し、食道裂孔部にて後腹膜組織内に迷走神 経後幹を確認、テーピングを行ら。後幹周囲の郭清を 末梢側へ進め、腹腔枝周囲の剥離郭清につなげて行く。 後幹より分岐する後胃枝は順次切離して行く。乙の剥 離層を確保しながら総肝動脈前面、腹腔動脈周囲、脾 動脈幹周囲を慎重に剥離して行くことにより、No.7. $8 \mathrm{a} ， 9,11$ のリンパ節が郭清される。 $\mathrm{sm}$ 癌では脾臓を 合併切除し、脾門部リンパ節の郭清に努める。 $\mathrm{m}$ 癌で は適宣リンパ節郭清を縮小する。リンパ節郭清の後、 胃を全摘する。再建回結腸は、回腸末端 $5 \mathrm{~cm}$ で切離、 上行結腸は盲腸を含めて $20 \mathrm{~cm}$ で切離する。間膜切離は 回結腸動脈起始部をで十分に行う。動脈起始部を中心 飞時計と逆方向に 90 度回転挙上儿食道回腸吻合、結腸 十二指暘吻合を行ら。間膜切踓を十分に行っておけげ血 管のねじれが問題となることはない。回圽結腸吻合も含め

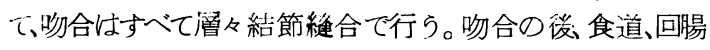
を横隔膜脚一固定、をた盲腸を横隔膜一固定し.盲腸部の 移動を防止する。度、十二指腸の剥離後腹膜への再固定 を行々、再建結腸の左方移觔および下方への直線化を防止 するととにより、術後のダンピング症候群発生を予防する。 
V 2-4 胃癌手術における下部食道括約機能温存手術

トヨ夕記空病院外科

安藤重満, 榊原堅式, 辻 秀樹, 西脇巨記

【目的】幽門側胃切除において下部食道噴門部に手 術侵襲が及ぶと術後腹部食道は縦隔内へ退縮し、His 角は鈍化して食道胃接合部（E G J ）の逆流防止機能 は著しく低下し、消化液の食道内逆流を来し易い状態 となる。下部食道括約（L E S ）機能は腹部食道の長 さと密接な関係にあることより、腹部食道をできるだ け長く確保することにより L E S 機能温存を図ること が可能と思われた。また胃全摘術においては食道と十 二指腸または空腸との間に挙上間置する空腸ループは 長い程逆流性食道炎は少なくなるが、迷走神経枝の切 離された空腸は蠕動運動障害を起こし食物のstasisの 原因となるので、食物の排出能をよくするには間置空 腸は短い方がよい。そこでL E S 機能の温存を図り間 置空腸を短くして検討した。

【対象と方法】腹部食道の長さを確保する方法とし て食道裂孔へルニアに対するHil1手術の基本である胃 後方固定の手技を応用した。幽門側胃切除例のうち体 上・中部癌で残胃が小さくなったものやリンパ節郭清 により腹部食道から噴門がぶらぶらになった症例（N =40）を対象に、E G J のレベルで残胃を小弯側に縫

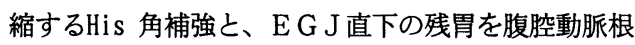
部頭側に存在する正中弓状靬帯に縫着する残胃正中弓 状靱帯固定を行って腹部食道の長さを確保した。また 胃全摘術（N=10）において食道空腹吻合部を正中弓 状靱帯に縫着する一方で、食道十二指腸間に間置する 空腸を $25 \mathrm{~cm}$ 程度と短くした。

【手術手技】胃全摘後の再建は $\rho$-double tract 法 にて行う。空腸は後結腸経路で挙上して断端より PCEEA 自動吻合器を挿入して、およそ $30 \mathrm{~cm}$ 肛門側の腸間 膜対側空腸と十二指腸断端を端側吻合する。次に空腸 断端より数 $\mathrm{cm}$ の空腸と食道を自動吻合器にて端側吻合 する。空腸の端側 $\rho$ 吻合は手繾いで行う。ここで食道 空腸吻合部を、腹腔動脈根部頭側で右横隔膜脚筋束前 面を横走する索状の正中弓状靱帯に 3 針で縫合固定し 、更に右横隔膜脚の左右筋束から食道裂孔を逆U字型 に食道壁と数針で固定する。これで腹部食道は $3-4 \mathrm{~cm}$ の長さがとれる。また幽門側胃切除術においてもその 手技を示す。

【結果とまとめ】幽門側胃切除術における弓状靶帯 固定により腹部食道は約 $3 \mathrm{~cm}$ 確保できた。 His 角も平 均で70度となり、100 度以上に鈍化した症例はなく逆 流症状を有するものは認められなかった。同様に胃全 摘術でL E S 機能温存を図り、間置空腸を20-25 cmに 短くしたが全例に逆流症状はみられず、食物の停滞感 も少なく、食事摄取量や体重維持の面で優れていた。
V $2-5$ 吻合部血流温存に留意した胃全剔術後 再建術

埼玉医科大学第一外科

山崎達爑、安西春幸、松本隆、長鳥直樹、

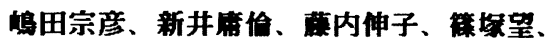

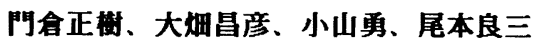

【はじめに】当科では、1990年1月より胃全剔術 後の再建法として、辺粶静腊の血流を完全に温存 したままRoux-enY法あるいは空閏間㨁法を行う Billroth II型再建法を取り入れ、良好な結果を得てい るので、その手技をビデオで供笔し報告する。【手

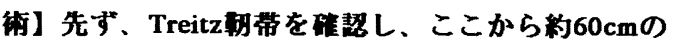
空期胿門何の部分を刢状㔖起に向って引き上げ、食 道の彻合予定部に十分到達することを礁洯する。次

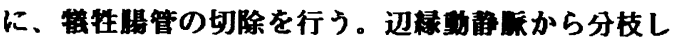

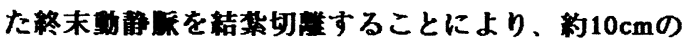

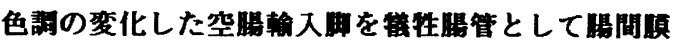

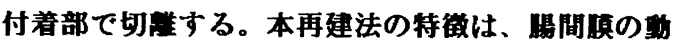

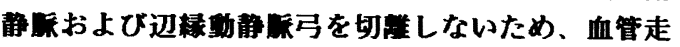
行の碓琶や血行遥断テストなしで、経雅の少ない外 科医でも安全かつ教実に、挙上する空第管を作成す ることができる点にある。Roux-en Y咖合では、 RetrocolicaにBillroth II型再建を行い、食道空䙹吻合 に繶いて空鹪肛門何断端を輸出用に吻合し $\rho$ 型吻合 を完成する。さらに、横行結睡間䐜の久損孔より、 空晹口何断端を引きだし、食道空睤吻合部から $40 \mathrm{~cm}$

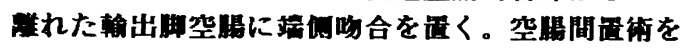
施行する场合では、 $\rho$ 型吻合が完了した後、食道空

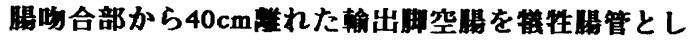
て約 $5 \mathrm{~cm}$ 切除する。あらたに、横行結㽢間㯖に久損 孔を設け、口四断端と十二指梛断端を吻合した啳、

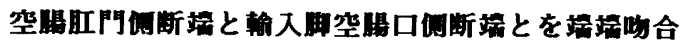
する。【結果】1990年1月から1995年12月までに本 再建法を行った症例は199例あり、合併症は䋖合不 全が4例 $2 \%$ 、吻合部狭察が 2 例 $1 \%$ と浦足すべき結果 であった。

【まとめ】辺程動解成の血流を完全に温存したまま Roux-en Y法あるいは空䁍法を行う Billroth II型 再建法について報告した。 
$\mathrm{V} 2-6$ 門側胃垔全摘術後の再建術式 - Jejunal pouch interposition (JPI)法 金沢大学第 2 外科

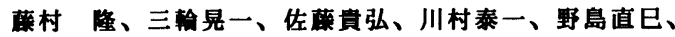
木南伸一、広野靖夫、津川浩一郎、伏田幸夫、西村元一、 杉山和夫、米村 僼、宮崎晩夫

[目的]Jejunal pouch interposition(以下JPI)再建術 の手技上の工夫点と、JPI再建術施行長期释過後の機能 の評佰について報告する。

[対象と方法]対象は1987年より当科で閒側胃严全摘 術を受けた胃癌患者のうち、根治度へとなった141例て

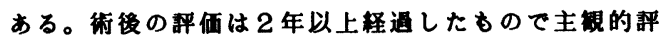
洒としてはアンケートを行い、回答のあったJPI再建法 (以下JPI群)87例と、同期間のBillroth I 再建法(以下 BI 群)45例について検㘪した。客钼的評価としては上 部消化管遁梘によるHis角の測定、上部消化管内梘鏡模 查による内眼的及び組学的残胃炎の程度 (シドニー システム)の評便を行い比較した。また核医学的な消

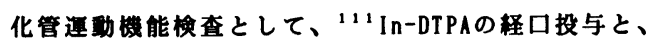
${ }^{\bullet 0} \mathrm{~T}$ c-PMI静注により、胃排泄時間、胆汁逆流の有無な どについて検討した。

[手術手技]JPI再建は口側に約 $10 \mathrm{~cm}$ 二重膈管pouch、

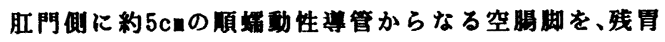
と十二指鸠の間に間酉する。この祭直動静㭛を空胞壁 に接して切断し特物管を切除することにより、自律 神释の損倡を予防する。空腸脚上端より約 $15 \mathrm{c}$ の部位 の空朋塈を切開し、ここからEndo GIAを二つ折りにし た空蜰内へ㨂入しガス压にて䋖合切閒を行う。粘膜か らの出血を確実に止血した後、Endo GIAによる操作を すう1回行うことにより 約 $10 \mathrm{~cm}$ 長のpouchが作成され る。残胃とpouchとの吻合は、吻合口を十分大きく取る ことにより残胃内の無滞を防止できる。

[結果]一日の食事回数が 3 回と術前の食事習颃が保持 された例はBI 群は87\%、JPI群は99\%と有意差が琶めら れた。術後の愁柝は胸やけ、ダンヒンング症状がBI群て 7\%、20\%てあったのに対して、JPI群では0\%、6\%と有意に 低率であった。His角は正常群、BI 群、JPI群の順に58度， 113 度,65度とJPI群では䧺持された。残冒内視鏡所見は BI群ては吻合部発赤、残胃発赤、㴔弱性、胆汁逆流か 100\%,91\%,91\%,64\%に琶められたのに対してJPI群では $33 \%, 10 \%, 24 \%, 14 \%$ と有意に低率であった。組機学的所見 はJPI群はBI群に比較して、残胃粘膜の炎应と大弯側 の萎䊒の程度が有意に眭度てあった。アイソトーフに よる排泄時間は、正常(47〜78分)に比較してBI群ては 全例短樎していたのに対してJPI群では20\%に見られた のみであった。胆汁の逆流はBI群ては75\%にみられた のに対してJPI群は10\%と有意に少なかった。

[蛣詥]以上よりJPI再建法により リザーバー機能、逆 流防止機能が保持されることが示され、胃覀全揞術後 の患者のQOLの萑持に有用と考えられた。
V 2-7 各領域胃癌に対する空腸毫形成再建の工夫 と成績 一患者QOLの評価とともに一

東海大学外科 2

宮治正雄、生越㽞二、近藤泰理、中村健司、

田島知郎、三富利夫

【目的と方法】近年の器械吻合器の進歩普及や胃癌手 術後の患者QOLを考虑して、空腸衰形成を利用した代用 胃形成を付加した再建術式が行われるようになってき た。しかし、手技が多少煩雑となり、長期の遠隔成綪の 報告も未だほとんど認められていないのが現状である。 我々は1991年より空腸衰形成を付加した再建術式を積 極的に取り入れ、これまで幽門側胃切除術に対し，空腸 形成ダブルトラクト再建 (以下JPD) 100例、胃全摘術 に対し，JPD40例、噴門側胃切除術 (噴切術)に対し，JPD

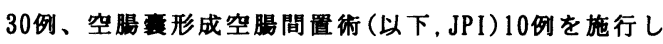
てきた。一方、我々は上部胃癌に対し、腊器温存の立場、 栄養、免疫学的回復が良好なことから積極的に噴切術を 取り入れてきた。進行胃癌に対しても小等全摘の形で N0.5の郭清とN0.4d，6のスダレ状郭清を加え，噴門側胃 切除術 (大李側約 $10 \mathrm{~cm}$ 残す)を施行している。最近は術 後内視鏡観察が容易なJPIを行い、良好な成樍を治めて いる。今回、各領域胃癌に対する空腸震形成再建術式の 薏応や手技上の工夫を述べ、これまでの成績と術後患 者QOLの評価を同時期施行したB-I 法やRoux-enY法、ダ ブルトラクト法など空腸毫非形成群と比較検討した。

【空腸霍形成再建の道応】肝硬変、心肺系合併症、糖尿 病なと明らかな合併症がない症例で、術前インフォー ムド・コンセントがとれた患者に対して行っている。

【手術手技、工夫と成績】1）幽門側胃切除(下部胃癌) 、胃全摘後JPD再建：(1)トライッ带より $15 \mathrm{~cm}$ の空腸切 離 (2)空渴・十二指晹吻合、噴切では空腸・残胃吻合 (EEA 28使用) (3)10-15cmの空腸萦を形成（GIA，サージセル使 用にて止血効果はかる) (4)胃空腸震吻合 (EEA31使用)、 全摘では食道・空腸震吻合 (EEA28) (5)空腸震閉鎖 (TA使 用) (6)空腸・空腸端側吻合 (手释い)施行の順で行ってい る。幽門側胃切除の術後 $1 、 2$ 年までの評価では同ステー ジのBillroth I 法に比し、小胃症状や体重の減少率は 少なく、術後内視鏡検査では有意に残胃炎、逆流性食道 炎は減少していた。QOLアンヶート調査では、空腸毫形 成群が非形成群に比し有意にQOLが良好であった。

2）噴門側胃切除後JPI再建（上部胃癌）：JPI再建は (1)トライッ帯より $15 \mathrm{~cm}$ の空腸切離 (2)15-20cmの空腸 霍を形成(GIA,サージセル使用にて止血効果はかる)(3) 食道・空腸赛吻合 (EEA28) (4)空腸喜・残胃吻合（手䋖い） (5)空渴・空腸端端吻合 (手縫い、或いはValtrac)施行の 順で行っている。術後、小胃症状や逆流症状は少なく、 幽門側残胃の内視鏡钼察も容易である。【結語】各領 域における合併疾患のない胃癌症例において空腸零形 成再建は患者QOLの面より意義あることと考えられた。 